\title{
Is it time for baclofen to be included in the official recommendations concerning the treatment of alcoholism?
}

\author{
Sebastian Masternak B,E, Nikodem Skoczeń A,D, Ewelina Dziwota D,E, Marcin Olajossy A,D,F \\ II Department of Psychiatry and Psychiatric Rehabilitation, Medical University of Lublin
}

\begin{abstract}
Alcohol dependence and its treatment is not an exactly resolved problem. Based on the EZOP [Epidemiology of Mental Disorders and Accessibility of Mental Health Care] survey, which included a regular analysis of the incidence of mental disorders in the population of adult Polish citizens, we were able to estimate that the problem of alcohol abuse in any period of life affects even $10.9 \%$ of the population aged 18-64 years, and those addicted represent $2.2 \%$ of the country's population. The typical symptoms of alcohol dependence according to ICD-10, include alcohol craving, impaired ability to control alcohol consumption, withdrawal symptoms which appear when a heavy drinker stops drinking, alternating alcohol tolerance, growing neglect of other areas of life, and persistent alcohol intake despite clear evidence of its destructive effect on life. At the moment, the primary method of alcoholism treatment is psychotherapy. It aims to change the patient's habits, behaviours, relationships, or the way of thinking. It seems that psychotherapy is irreplaceable in the treatment of alcoholism, but for many years now attempts have been made to increase the effectiveness of alcoholism treatment with pharmacological agents. In this article we will try to provide a description of medications which help patients sustain abstinence in alcoholism therapy with particular emphasis on baclofen.
\end{abstract}

Keywords: baclofen, alcohol abuse

\section{Introduction}

Alcohol dependence and its treatment is not an exactly resolved problem. Based on the EZOP survey, which included regular analysis of the incidence of mental disorders in the population of adult Polish citizens, we were able to estimate that the problem of alcohol abuse in any period of life affects even $10.9 \%$ of the population aged 18-64 years, and those addicted represent $2.2 \%$ of the country's population. The diagnosis of alcohol dependence in men is approx. 10 times higher than in women (4.1\% vs. $0.4 \%$ ). Translated into absolute numbers, we can say that about 850000 adult Poles are affected by alcohol dependence [1]. It is estimated that $40-60 \%$ of deaths due to injuries are associated with alcohol consumption [25]. The typical symptoms of alcohol dependence according to ICD-10 include alcohol craving, impaired ability to control alcohol consumption, withdrawal symptoms which appear when a heavy drinker stops drinking, alternating alcohol tolerance, growing neglect of other areas of life, and persistent alcohol intake despite clear evidence of its destructive effect on life. The diagnosis according to ICD-10 is based on finding the symptom or lack thereof, it is also necessary to take into account the criterion of time $[26,27,28]$. Developed by the American Psychiatric Association and published in 2013, the fifth edition of DSM [Diagnostic and Statistical Manual of Mental Disorders] includes a category of "Substance-related and addictive disorders". Currently, this classification does not separate the already addictive and harmful use of alcohol. Instead, there is the category of " Alcohol Use Disorder" (AUD), which allows diagnosing the health problem and its severity based on the number of symptoms and the frequency of their occurrence $[29,30]$. Unfortunately, it is only seemingly simple to self-diagnose alcoholism. An alcoholic develops very strong defence mechanisms which make it difficult to identify the problem and start treatment. For this reason, it often takes years before an addicted individual decides to get therapy.

Treatment of alcoholism is a difficult long-term process. In Poland, alcoholism is treated on an outpatient basis in out-patient clinics and departments, as well as in day-care or 24-hour detoxification units. The main objective of treatment of alcoholism in Poland is for the patient to completely abstain from alcohol. Western European countries in the recent years have been developing alcohol harm reduction programs addressed to patients for whom total abstinence is unattainable or perceived as too radical [2]. At the moment, the primary method of alcoholism treatment is psychotherapy. It aims to change the patient's habits, behaviours, relationships, or the way of thinking. Such treatment is continued for many months. Valuable supplements to psychotherapy, are the meetings of Alcoholics Anonymous (AA) groups, during which abstinent alcoholics help one another to stay sober [32, 33]. 
It seems that psychotherapy is irreplaceable in the treatment of alcoholism, but for many years now attempts have been made to increase the effectiveness of alcoholism treatment with pharmacological agents. The next section provides a description of medications which help patients sustain abstinence in alcoholism therapy.

\section{Medications used in the pharmacotherapy of alcoholism}

Disulfiram is perhaps the best known medication used to sustain sobriety. It works by inhibiting aldehyde dehydrogenase, so the person who has drunk alcohol, while under the influence of disulfiram, experiences symptoms of acetaldehyde poisoning, which include headache, nausea, vomiting, sweating, and heart palpitations. The drug does not directly affect craving; it has an aversive effect on the patient, as it arouses fear of sideeffects of alcohol consumption. For disulfiram therapy to bring benefits, the patient must be informed of the consequences of drinking alcohol during the treatment. Disulfiram therapy, however, has a high rate of noncompliance, particularly when the drug is being administered orally. Currently, due to the high risk of toxicity (when the drug is ingested together with alcohol), and unclear effectiveness in preventing relapse of alcoholism, physicians move away from using disulfiram, and some recommendations do not advocate its routine use [3].

Acamprosate is a medicine which reduces the excitatory effect of amino acids such as glutamate and NMDA. Currently, a large role in this process is being attributed to the modulation of glutamate receptors mGluR5 [4]. Besides, acamprosate is also known to exert an action on GABA receptors and the opioid system [5]. Acamprosate reduces the subjective feeling of pleasure after consuming alcohol and reduces the symptoms of the withdrawal syndrome. In addition, it has been reported to have a protective effect on nerve cells exposed to damage by the neurotoxic effect of the withdrawal syndrome [6]. It is a safe drug, which can be taken by people with impaired liver function. Also, it does not produce dangerous interactions with other medications used to treat alcoholism, such as antidepressants, anxiolytics, disulfiram, naltrexone, and neuroleptics. However, acamprosate can only be incorporated in therapy on the condition that the patient sustains abstinence, though single alcohol intake episodes are not an indication to discontinue therapy. Moreover, acamprosate may not be used in people with renal dysfunction.

Naltrexone is an opioid receptor antagonist with the greatest affinity for $\mu$ receptors. It works by weakening the euphoric effects of alcohol, leading to a reduction in arousal experienced by the reward/punishment system of a patient after alcohol intake. Naltrexone reduces relapse rate in patients who sustain abstinence [7] and, in contrast to acamprosate, can also be effectively used in people who want to reduce the amount of alcohol consumed [8] . It appears that this medication is more effective than acamprosate in relieving alcohol craving and preventing binge drinking [9]. On the minus side, patients treated with naltrexone have been observed to more frequently experience side effects such as anxiety, insomnia, mood disorders, headaches, gastric complaints, as well as erectile dysfunction or urinary retention. Also, naltrexone cannot be used in patients with liver dysfunction and severe renal disease, which reduces the group of patients eligible to use it.

Another antagonist of opioid receptors (especially $\mu$ and d receptors) is nalmefene. It is a drug used in people who are unwilling or unable to sustain total abstinence. The patient is instructed to take the medication 'as needed', whenever he or she feels the urge to consume alcohol. The best results are achieved when the drug is ingested 1-2 hours before drinking. Nalmefene reduces the pleasurable sensations caused by the consumption of alcohol, as a result of which the patient drinks less. Nalmefene, similarly to naltrexone, cannot be taken by people suffering from severe kidney and liver failure; it also produces side effects similar to naltrexone.

\section{Recommendations}

Recommendations of various national societies for the treatment of addictions concerning pharmacotherapy of alcoholism are similar. For example, the French Society for the Treatment of Alcoholism (Société française d'alcoologie) recommends acamprosate and naltrexone as the first-line medications, of course, in conjunction with psychotherapy. Disulfiram is described as a second-line drug, which can be used only when suitable conditions are met. The French Society also allows administration of high doses of baclofen (up to $300 \mathrm{mg}$ per day) as second-line treatment [2].

The drugs recommended by the Australian Pharmaceutical Benefits Scheme are also acamprosate and naltrexone. In Australian clinical practice, physicians also prescribe disulfiram, although some of the guidelines do not recommend it because of the high risk of toxicity (in cases the patient drinks alcohol during treatment), and because there is no sufficient evidence for its effectiveness [3]. Topiramate and baclofen are often used in clinical practice, but they have not been officially approved for the treatment of alcoholism. We should certainly add to this list so well-known models and principles of alcohol abuse pharmacological treatment as the standards of American agency NIAAA (National Institute on Alcohol Abuse and Alcoholism), British agency NICE (National Institute for Health and Clinical Excellence), American Psychiatric Association (APA), British Association for Psychopharmacology (BAP), and at the end of the international example, the World Health Organization ( WHO) [30,34]. 
In Poland, we have standards relating to the treatment of alcohol dependence using psychotherapy. With respect to pharmacological treatment Pharmacovigilance Section of the Polish Society for the Study of addictions (PTBU), and Section psychopharmacology Polish Psychiatric Association (PTP) give recommendations. These recommendations are intended to approximate the Polish practice to rules of conduct, recommended in current international psychopharmacology [31]. Polish recommendations of the State Agency for Solving Alcohol Problems (Państwowa Agencja Rozwiązywania Problemów Alkoholowych), unfortunately, largely neglect the issue of pharmacotherapy of alcoholism devoting just a few remarks to it. The preferred pharmacological agents for the treatment of alcoholism are acamprosate, naltrexone and nalmefene. Disulfiram is approved for short-term application but only in oral form and not in the form of subcutaneous implementations which were commonly used in the past [10]. Statements about baclofen were presented during the 45 Congress of Polish Psychiatrists in Katowice in June 2016.

To sum up, recommendations of various organizations around the world speak mainly about the use of the two besttested drugs: naltrexone and acamprosate. In addition, they mention the possibility of using disulfiram in some specific cases. In many countries, however, an increasing interest has been taken in another medication the effectiveness of which is not yet sufficiently proven for it to be included in official recommendations, but reports of its therapeutic properties do not allow doctors to remain indifferent to it. This drug is called baclofen.

\section{What is baclofen?}

Baclofen, similarly to acamprosate, is a derivative of $\gamma$-aminobutyric acid (GABA). It was introduced into clinical practice already in the 1960s and is still used as a spasmolytic agent in such conditions as multiple sclerosis, spinal cord injury, stroke, cerebral palsy, and head trauma. Recently, however, there has been more and more talk about the use of baclofen in the treatment of alcoholism. Like any innovative method, also baclofen treatment polarizes opinion among both physicians and addicts (it is enough to read the fora), so it is worth taking a closer look at this issue. Baclofen works in the central nervous system by activating metabotropic GABA $\mathrm{B}$ receptors. By exerting this action, it increases nerve cell membrane conductance to sodium and potassium ions while reducing the conductance to calcium ions, which decreases the excitability of the cell. This effect has long been used in reducing muscle spasticity; however, it seems that it is also associated with the aversive effect of baclofen. This can be linked to the fact that alcohol acts through the GABAergic system, activating other receptors called ionotropic $\mathrm{GABA}_{\mathrm{A}}$. GABAA receptors are also tar- geted by benzodiazepines, which implies their effectiveness in detoxification of people recovering from a drinking bout. The use of benzodiazepines in long-term treatment, however would be pointless, since they would quickly become another addictive agent with all the consequences of such a situation. Numerous clinical and experimental studies indicate that acting on $\mathrm{GABA}_{\mathrm{B}}$ receptors effectively activates the function of the GABAergic system and can inhibit addiction-motivated behaviour [11]. Below, we try to demonstrate the effectiveness of baclofen, citing the results of several such experiments.

\section{Clinical tests}

Research on the use of baclofen in alcoholism does not have a long history. A pioneer in this field was professor Olivier Ameisen, a cardiologist with French roots, who in his book The End of My Addiction (2009) described his own experiences of recovering from addiction with the help of baclofen. One of the first works inspired by Professor Ameisen's case, aimed at testing the efficacy of baclofen on a larger patient population, was a study started in 2008 by Renaud de Beaurepaire [12]. Beaurepaire analysed 100 alcohol-dependent patients, of whom 87 survived to the end of the two-year study period. Before treatment, all the patients had had drinking bouts during which they had consumed alcohol every day in large quantities. Each patient had made unsuccessful attempts to quit drinking with the help of addiction treatment centres, medication or Alcoholics Anonymous. During the first visit, each patient was instructed to take a small dose of baclofen, which was then increased as needed (mean maximum dose during treatment was $147 \mathrm{mg} / \mathrm{d}$ ). The patients were not recommended other forms of concomitant therapy, and were allowed to consume alcohol during the study. During successive follow-up visits at 3, 6, 12 and 24 months of starting therapy, patients were assigned to risk groups according to WHO, based on the amount of alcohol consumed daily during the 4 weeks prior to the visit (the researcher also tried to take into account the patients' subjective assessment of craving but no meaningful results were obtained). At the onset of the experiment, all of the patients were in a high-risk group (alcohol intake of more than $60 \mathrm{mg} / \mathrm{d}$ for men and $40 \mathrm{mg} / \mathrm{d}$ for women). During therapy, however, a significant decrease in the number of patients in this group was observed. The decrease was $16 \%$ after 3 months, $27 \%$ after 6 months, $29 \%$ after one year and $25 \%$ after two years of treatment. Most of the patients reduced the consumption of alcohol so strongly during the experiment, that they found themselves among low-risk patients according to the WHO drinking guidelines as early as three months after the start of the therapy (consumption of less than $40 \mathrm{~g} / \mathrm{d}$ for men and less than $20 \mathrm{~g} / \mathrm{d}$ for women) and remained in 
that group until the end of the study period $(50 \%$ at 3 months, $52 \%$ at 6 months, $48 \%$ at 12 months and $50 \%$ after 24 months from the initial visit). The remaining patients were in the medium risk group.

The analysis showed no correlation between daily dose of baclofen and response to therapy in individual patients. Also, such factors as gender, BMI, family situation, and profession were without an effect on the size of the effective dose. It was determined, however, that patients who consumed larger quantities of alcohol needed a higher dose of baclofen than those who drank less. Most patients experienced mild side effects of the treatment. The most common were somnolence, fatigue, difficulty sleeping, dizziness and paraesthesia. Other authors also reported favorable changes in alcohol consumption induced by baclofen[23].

Beaurepaire's study without doubt confirms the thesis that baclofen may be successfully used in the pharmacotherapy of alcoholism. It does not, however, answer the question how the effectiveness of baclofen compares with the effectiveness of the drugs already approved and regularly used in the treatment of alcoholism.

An attempt to answer this question was made in a study conducted in India, during which researchers compared the effectiveness of baclofen with that of acamprosate, which is recognized as the first-line medication in alcohol treatment recommendations around the world [13]. The study involved 549 subjects divided into two groups. The subjects received treatment at the Center for Addiction Medicine which is part of the Institute of Mental Health and Neurosciences (NIMHANS) in Bangalore. The patients were diagnosed with addiction based on two evaluations - a 166-item questionnaire which was used to identify preliminarily the patients' addiction profiles, life situation, and other relevant clinical aspects of addiction, and a consultation with a psychiatrist. The degree of addiction was assessed on the basis of the frequency of drinking and the amount of alcohol consumed. Patients included in the study had started addiction treatment in the period from January 2013 to January 2014, were not addicted to other substances (except nicotine), were treated with baclofen or acamprosate, and did not discontinue medications without permission. All persons included in the analysis were male and their mean age was 38.8 years, and the mean duration of addiction was 12.6 years. Mean alcohol intake was 14 units per day. The time through which the patients sustained total abstinence was adopted as the criterion for evaluating treatment outcome. Patients were divided into two groups. One group was to receive baclofen, and the other - acamprosate. The duration of addiction, patients' age, age at onset of alcohol dependence, and mean daily alcohol intake were similar in both groups.
The experiments showed that the time elapsed from the start of treatment to the first drinking episode was 4.44 months in the group treated with baclofen and 3.73 months in the acamprosate group. The difference was statistically significant $(\mathrm{P}=0.01)$.

In a further part of the study, the authors examined how the duration of abstinence achieved in the group treated with baclofen was affected by factors such as mean daily alcohol intake, current age, age at the onset of alcoholism, positive family history, duration of addiction, and baclofen dose in $\mathrm{mg} / \mathrm{d}$. It was shown that the only variables which had a statistically significant impact on the duration of abstinence were the mean amount of alcohol consumed daily and baclofen dose. The Indian study leads to the conclusion that off-label use of baclofen may be more effective than the use of acamprosate, a clinically approved medication. Another reason why $b a$ clofen seems to be a good alternative to other medications used in alcoholism is the fact that its effectiveness depends only on the amount of alcohol consumed and the dose of the drug itself and is not determined by the 'typology of alcoholism' as is the case with acamprosate, naltrexone and topiramate [14].

When interpreting the results of the studies cited above, however, one should take into account the fact that there are many exponents of the efficacy of alcoholism treatment, such as the rate of abstinence, time to relapse to heavy drinking, or results of clinical chemistry tests. The only exponent of the effectiveness of treatment taken into account in the study cited was mean duration of total abstinence.

Another aspect of the effectiveness of baclofen therapy was described in 2015 in France [15]. Patients treated with baclofen at doses increased from $15 \mathrm{mg} /$ day at baseline to $180 \mathrm{mg} / \mathrm{d}$ after 3 months of treatment (the dose was increased by $15 \mathrm{mg} / \mathrm{d}$ per week) were asked to regularly measure the intensity of craving using the obsessivecompulsive drinking scale (OCDS). As a result of the applied therapy, a decrease in craving was observed in all patients, though not every patient derived a measurable benefit from the therapy. The average score on the 56item OCDS scale decreased from 21 points at baseline to 14 points at the end of therapy. This may seem a mediocre result, but one important aspect should be taken into account. After analyzing the results of the study, the authors divided the study population into two groups of patients - good responders to baclofen treatment (38\% of patients) and poor responders. Among the good responders, the mean score on OCDS decreased from 21 points at baseline to about 8 as early as three weeks after treatment, when they were receiving a dose of $45 \mathrm{~g} / \mathrm{d}$ of $b a$ clofen. A further increase in dose, no longer led to significant improvements in treatment effects. Among patients resistant to treatment with baclofen, craving decreased by 
several points as late as after two months of treatment (and at a much higher dose, $135 \mathrm{mg} / \mathrm{d}$ ); craving continued to slightly decrease in those patients until the end of therapy (to finally reach about 16 points). As in other studies, there was no significant correlation between the effectiveness of treatment and variables such as age, gender, body height and weight, or the results of laboratory tests such as AST, ALT, prothrombin time, MCV, GGT and CDT. Patients poorly responsive to baclofen, however, were observed to have higher concentrations of creatinine and alkaline phosphatase. It can be hypothesized that those patients had been in a worse health condition than those who derived a measurable therapeutic benefit from $b a$ clofen therapy. That study, however, was flawed by not including a control group, so it is impossible to estimate the impact of the placebo effect on the results. Besides, the study group was small. Nevertheless, the experiment leads to important conclusions - some patients respond really well to treatment with baclofen even at small doses, while for others (who unfortunately constitute the majority) the effectiveness of this therapy is not satisfactory and they need to receive high doses of the drug to even slightly lower their craving. It would be very beneficial to find traits, more unambiguous than the slightly lower creatinine and alkaline phosphatase levels, which predispose patients to respond well to baclofen treatment.

Of course, there are also studies which question the effectiveness of treatment with baclofen. For example, Garbutt's study conducted in 2010 on a group of 80 patients suggested that the efficacy of baclofen in increasing total abstinence and preventing heavy drinking spells was comparable to that of placebo. The only difference between the baclofen group and the placebo group was that the former had slightly lower levels of anxiety [16].

\section{Why should baclofen not be used?}

Given the promising results of research, it is difficult not to wonder why baclofen is not used as a first-line medication in the treatment of alcoholism. Perhaps, the main reason is the lack of confidence in the drug caused by the fact that it only has a very short history of use in this disease. Also, one must not forget about the side effects of baclofen therapy. One such adverse effect is the withdrawal syndrome with a severity comparable to that of the alcohol discontinuation syndrome. Negative effects of cessation of baclofen treatment have been reported by physicians exchanging their experiences, patients writing on alcohol addiction fora and researchers [17]. Withdrawal symptoms include hallucinations, delusions, confusion, disorientation and nausea. Tachycardia, tremors, convulsions, autonomous disorders, hyperthermia and muscle stiffness have also been observed [18]. There are known cases of abuse of baclofen connected with its CNS depressant properties. Baclofen abusers describe its action as relaxing and soothing. Such individuals may develop both mental and physical dependence [19]. Rigal et al. in their article indicated that alertness disorders and depression were the adverse effects that most frequently led to stopping baclofen. Bouts of somnolence and episodes of hypomania are according to these authors, potentially the most dangerous side effects. The authors also noted that women had significantly more side effects than men [24].

These reports largely explain why practitioners are reluctant to use baclofen to treat alcoholism. Unfortunately, the risk of addiction is not the only drawback of this drug.

The medical literature describes cases of epilepsy induced by baclofen. For example, a 35-year-old patient of the Queen Mary University Hospital in London, who had never had epileptic fits before, began to experience seizures of increasing frequency after she started receiving baclofen therapy for leg muscle stiffness. The frequency of seizures, in the worst period, was 200 during two weeks! The patient found herself in a condition requiring mechanical ventilatory support. After gradual discontinuation of baclofen therapy and introduction of phenytoin and valproate, the seizures stopped completely [20].

Another case was a 47-year-old man who suffered seizures after he had abruptly increased his alcohol consumption while receiving baclofen for alcohol dependence. This patient had been treated with increasing doses of baclofen, which lowered his average daily intake of alcohol from $150 \mathrm{~g} / \mathrm{d}$ to about $50 \mathrm{~g} / \mathrm{d}$. Unfortunately, at a daily dose of $240 \mathrm{mg}$ of baclofen, he had a five-day heavy drinking episode (more than $160 \mathrm{~g} / \mathrm{d}$ ). During this period, he suffered his first tonic-clonic seizure, which required hospitalization. The seizures were repeated, and so the doctors had to discontinue baclofen. It can be conjectured that it was the combination of high doses of alcohol with high doses of baclofen that triggered this patient's seizures [21].

It is not known what predisposition led to such responses to the administration of baclofen in those patients. Intuitively, a likely determinant would be a history of past seizures, though not in the cases discussed above. Attempts at verifying this thesis were already made in the 1980s, but the studies conducted at that time did not show a clear increase in the frequency of seizures in people with epilepsy as a result of administration of baclofen. [22]

\section{Conclusion}

According to the results of clinical trials, the efficacy of baclofen in the pharmacotherapy of alcohol dependence appears to be very promising. This medication may have an even greater therapeutic potential than the currently used agents. In some countries, baclofen, slowly but steadily is making its way into the canon of alcoholism treatment and begins to appear in recommendations. Before, 
however, we can consider baclofen therapy to be a salvation for alcohol dependent patients, we have to keep abreast of further reports on both the effectiveness and safety of its use, since the drug has a very short history (in this application), and only when more reliable research is done, will we be able to say for sure whether baclofen is a new way to solving the problem of alcoholism or just a dead end.

\section{Conflict of interest}

The authors have declared no conflict of interest.

\section{References:}

1. Kiejna A, Piotrowski P., Adamowski T., Moskalewicz J., Wciórka J., Stokwiszewski J., Kessler R. Rozpowszechnienie wybranych zaburzeń psychicznych $\mathrm{w}$ populacji dorosłych Polaków $\mathrm{z}$ odniesieniem do płci I struktury wieku - badanie EZOP Polska. Psychiatr. Pol. 2015; 49(1): 15-27.

2. Rolland B., Paille F., Gillet C., Rigaud A., Moirand R., Dano C., Dematteis M., Mann K., Aubin H. Pharmacotherapy for Alcohol Dependence: The 2015 Recommendations of the French Alcohol Society, Issued in Partnership with the European Federation of Addiction Societies. CNS Neurosci. Ther. 2016; 22(1): 25-37.

3. VA/DoD Clinical practice guideline for management of substance use disorders (SUD). Department of Veterans Affairs, Department of Defense. Version 2. Washington, DC: Department of Veterans Affairs; 2009: 67.

4. De Witte P., Littleton J., Parot P., Koob G. Neuroprotective and abstinence-promoting effects of acamprosate: elucidating the mechanism of action. CNS Drugs 2005;19: 517-537.

5. Habrat B., Akamprozat $w$ zapobieganiu nawrotom picia i zmniejszaniu ilości wypijanego alkoholu przez osoby uzależnione Przegląd badań klinicznych. Alkohol. Narkom. 1998; 31(2): 147-159

6. Mann K., Kiefer F., Spanagel R., Littleton J. Acamprosate: recent findings and future research directions. Alcohol. Clin. Exp. Res. 2008; 32: 1105-10.

7. Srisurapanont M., Jarusuraisin N. Naltrexone for the treatment of alcoholism: a meta-analysis of randomized controlled trials. Int. J. Neuropsychopharmacol. 2005; 8: 267-80.

8. Australian Government Department of Health and Ageing. Guidelines for the treatment of alcohol problems. Canberra: Commonwealth of Australia; 2009.

9. Maisel N.C., Blodgett J.C., Wilbourne P.L., Humphreys K., Finney J.W. Meta-analysis of naltrexone and acamprosate for treating alcohol use disorders: When are these medications most helpful?. Addiction. 2013; 108(2): 275-293.

10. Państwowa Agencja Rozwiązywania Problemów Alkoholowych; Rekomendacje do realizowania i finansowania gminnych programów profilaktyki i rozwiązywania problemów alkoholowych w 2016 roku; Wydanie I Warszawa 2015

11. Agabio R., Colombo G. Receptor GABAB jako cel terapeutyczny w uzależnieniu od substancji psychoaktywnych - od baklofenu do pozytywnych modulatorów allosterycznych. Psychiatr. Pol. 2015; 49(2): 215-22.

12. Beaurepaire R.; Suppression of Alcohol Dependence Using Baclofen: A 2-Year Observational Study of 100 Patients. Front. Psychiatry. 2012; 3: 103. http://journal.frontiersin.org/article /10.3389/fpsyt.2012.00103/full (dostęp 11.08.2016)

13. Shukla L., Shukla T., Bokka S., Kandasamy A., Benegal V., Murthy P., Chand P. Correlates of Baclofen Effectiveness in Alcohol Dependence. Indian J. Psychol. Med. 2015; 37(3): 370-373.
14. Lesch O.M., Riegler A., Gutierrez K., Hertling I., Ramskogler K., Semler B., et al. The European acamprosate trials: Conclusions for research and therapy. J. Biomed. Sci. 2001; 8: 89-95.

15. Imbert B., Alvarez J., Simon N. Anticraving Effect of Baclofen in Alcohol-Dependent Patients. Alcohol. Clin. and Exp. Res. 2015; 39(9): 1602-1608.

16. Garbutt J.C., Kampov-Polevoy A.B., Gallop R., Kalka-Juhl L., Flannery B.A. Efficacy and safety of baclofen for alcohol dependence: a randomized, double-blind, placebo-controlled trial. Alcohol Clin. Exp. Res. 2010; 34(11): 1849-1857.

17. Leo R.J., Baer D. Delirium Associated With Baclofen Withdrawal: A Review of Common Presentations and Management Strategies. Psychosomatics 2005, 46, 503-507.

18. Richter E., Baldovini A., Blasco V., Leone M., Albanese J. About baclofen withdrawal syndrome. La Presse Médicale 2016; 45(5): 547-548 doi: 10.1016/j.lpm.2016.02.012.

19. Sein Anand J., Habrat B., Sut M., Korolkiewicz R. Nadużywanie substancji teoretycznie bez znanego potencjału uzależniającego przegląd przypadków. Przegl. Lek. 2009; 66 (6): 290-292.

20. Rush J.M., Gilbert F.D. Baclofen-induced epilepsy. J. R. Soc. Med. 1990; 83: 118-119.

21. Rolland B., Deheul S., Danel T., Bordet R., Cottencin O. A Case of De novo Seizures Following a Probable Interaction of High-Dose Baclofen With Alcohol; Alcohol Alcohol. 2012; 47(5): 577-580.

22. Terrence CF, Fromm GH, Roussan MS. Baclofen; Its Effect on Seizure Frequency; Arch Neurol. 1983; 40(1): 28-29.

23. Rigal L., Alexandre-Dubroeucq C., de Beaurepaire R., Le Jeunne C., Jaury P. Abstinence and 'low-risk' consumption 1 year after the initiation of high-dose baclofen: a retrospective study among 'high-risk' drinkers. Alcohol Alcohol. 2012; 47(4): 439-442.

24. 24 Rigal L., Legay Hoang L., Alexandre-Dubroeucq C., Pinot J., Le Jeunne C., Jaury P. Tolerability of High-dose Baclofen in the Treatment of Patients with Alcohol Disorders: A Retrospective Study. Alcohol Alcohol. 2015; 50(5): 551-557.

25. Grzybowski A. Alkoholizm - Stale aktualny problem zdrowotny społeczeństwa polskiego. Aktywność samorządu w zakresie profilaktyki alkoholowej. Nowiny Lek. 2005, 74, 2, 244-250.

26. World Health Organization (WHO). The ICD -10 Classification of Mental and Behavioural Disorders: Clinical Descriptions and Diagnostic Guidelines. Geneva 1992: World Health Organization

27. Puzyński S., Wciórka J. (polish eds.). ICD - 10. Klasyfikacja zaburzeń psychicznych i zaburzeń zachowania. Opisy kliniczne i wskazówki diagnostyczne. Uniwersyteckie Wydawnictwo Vesalius oraz IpiN, Kraków - Warszawa 2000: 69-79.

28. Habrat B., Steinbarth-Chmielewska K., Baran-Furaga H. Zaburzenia psychjiczne I zaburzenia zachowania związane z przyjmowaniem substancji psychoaktywnych. W: Pużyński S., Rybakowski J., Wciórka J. (eds.): Psychiatria. Psychiatria kliniczna. Wydanie II. Elsevier Urban\&Partner, Wrocław 2011, tom 2,3: 158-194.

29. American Psychiatric Association. Diagnostic And Statistical Manual of Mental Disorder. $5^{\text {Th }}$ edition (DSM-5). Substance related and addictive disorders. American Psychiatric Association, Washington 2013.

30. Samochowiec J., Habrat B., Cierpiałkowska L., Wojnar M., Bieńkowski P. leczenie zaburzeń związanych $\mathrm{z}$ używaniem alkoholu I innych substancji psychoaktywnych. W: Jarema M. (ed.) Standardy leczenia farmakologicznego niektórych zaburzeń psychicznych. Viamedica, Gdańsk 2015; 6: 250-286.

31. Bieńkowski P., Habrat B., Jarema M., Mierzejewski P, Samochowiec J., Wojnar M., Rybakowski J. Długoterminowa farmakoterapia wspierająca utrzymywanie abstynencji lub zmniejszająca spożycie alkoholu u osób uzależnionych od alkoholu. Zalecenia 
Sekcji Farmakoterapii Polskiego Towarzystwa Psychiatrycznego (PTP). Farmakoter. Psych. Neurol. 2013; 3-4: 133-139.

32. Fudała J. Leczenie osób uzależnionych od alkoholu w Polsce. W: Miller P. (red) Terapia uzależnień. Metody oparte na dowodach naukowych. supp. 1. Wydawnictwa Uniwersytetu Warszawskiego, Warszawa 2013: 441-461

33. Mellibruda J., Sobolewska-Mellibruda Z. Integracyjna psychoterapia uzależnień. Teoria I praktyka. Wydanie II (Wydanie I: 2006). Instytut Psychologii Zdrowia PTP, Warszawa 2011.

34. Haass-Koffler C.L., Leggio L., Kenna G.A. Pharmacological Approaches to Reducing Craving in Patients with Alcohol Use Disorders. CNS Drugs 2014; 28 (4): 343-360.

\section{Correspondence address}

Nikodem Skoczeń, II Department of Psychiatry and Psychiatric Rehabilitation, Medical University of Lublin, ul. Głuska 1, 20-439 Lublin, e-mail: nikodem.skoczen@onet.pl

Otrzymano: 03.06.2016

Zrecenzowano: 09.06.2016

Otrzymano po poprawie: 10.06 .2016

Ponownie zrecenzowano: 12.06 .2016

Przyjęto do druku: 20.06.2016 